\title{
Breast feeding and protection against neonatal sepsis in a high risk population
}

Rifat Nisar Ashraf, Fehmida Jalil, Shakila Zaman, Johan Karlberg, Shaukat Raza Khan, Bo S Lindblad, Lars $\AA$ Hanson

\begin{abstract}
Protection against neonatal sepsis by breast feeding was investigated in a developing community. A case-control study was carried out with 42 cases from a hospital and 270 controls, matched for age and socioeconomic conditions from the community. Exclusive breast feeding was extremely rare, most babies being partially breast fed and a few being given formula feed or animal milk.

A highly significant odds ratio of 18 was obtained, showing that even partial breast feeding protects against neonatal sepsis in such a population.
\end{abstract}

Neonatal sepsis is a major cause of morbidity and mortality among young infants. In developed countries the incidence of neonatal sepsis is about $3 / 1000$ live births. ${ }^{12}$ A comparable figure for Pakistan is not available, but it should be higher as infections are the main cause of neonatal mortality there. A study from Mayo Hospital, Lahore, showed that cases of neonatal sepsis comprised $30 \%$ of the total neonates admitted with infections. ${ }^{3}$ Mortality in neonatal septicaemia remains high, $45 \%$ being reported from Saudi Arabia ${ }^{4}$ and $12 \%$ from Sweden. ${ }^{5}$ In an ongoing longitudinal study of children in Lahore, Pakistan, the initial estimates suggest that of the total deaths in the neonatal period $12 \%$ are the result of neonatal sepsis (unpublished data). In this population, breast feeding is not usually initiated before $48-120$ hours after birth and certain other food and fluids are fed instead. ${ }^{6}$ These foods and fluids are often contaminated with bacteria, mainly Gram negative (I Alderberth and $\mathrm{K}$ Khalil, personal communication).

A study from Sweden suggested that breast milk protects against neonatal septicaemia and meningitis caused by Gram negative bacteria. ${ }^{7}$ We undertook a case-control study in a high risk population in Lahore, Pakistan to find out if breast feeding can protect against neonatal sepsis.

\section{Patients and methods}

STUDY GROUPS

A matched case-control study was carried out with 42 cases of neonatal sepsis that had been admitted to hospital and 270 controls selected from the community in Lahore, Pakistan.

The cases (3-28 days old) were consecutive patients admitted to hospital with a diagnosis of septicaemia from January to August 1987. Nine cases were 3-7 days old when admitted and had become ill at the ages of $3,3,3,4,4,5,5,6$, and 7 days. The other 33 had become ill and were admitted when they were aged 8-28 days. Those included were severely ill term neonates admitted to the nursery of the Mayo Hospital, Lahore, with a clinical diagnosis of septicaemia based on three or more of the following features: hypothermia or hyperpyrexia, hypotonia, lethargy, refusal to feed, and jaundice or signs of meningeal irritation, or both. Neonates with severe infectious diseases such as pyoderma, diarrhoea, or radiologically diagnosed bronchopneumonia were excluded, as were premature infants, twins, babies with congenital malformations, and asphyxiated neonates. The provisional diagnosis was always confirmed by the senior consultants. Because antibiotic treatment had often been instituted before admission and the cultures that had been done were not of a high enough quality to ensure scientific reliability, the results of the blood cultures have not been considered.

The controls were identified within the community and were of the same socioeconomic group as the cases. The controls were neonates without apparent infection, identified from the community birth registers within one to two weeks after a case had been admitted (with a maximum difference in the date at birth of seven days), controlling for differences in the mode of feeding in relation to the season of the year. ${ }^{8}$ We aimed to select eight controls for each case matching for area of living and date of birth to within seven days. The number of controls found, however, was less than expected. The mean number of controls for each case was 6.4 (range 4-8), as it was not always possible to find eight infants with matching birth dates. We did not regard hospital patients as suitable controls as only extremely ill infants are referred or directly admitted. Most of them have been ill for several days or have various anomalies that would militate against them being breast fed.

The mothers were interviewed by trained health workers who were unaware of the objective of the study, using the same standardised questionnaire for both cases and controls. Risk factors such as sex, birth order, place of delivery, qualification of birth attendant, interval between rupture of membranes and delivery, and techniques of cord care, were recorded. A detailed retrospective history of feeding, starting from the day of birth (including frequency of breast feeding) was also recorded. The pattern that evolved was classified into three groups: exclusive breast feeding; partial breast feeding - that is, those who started breast feeding after or in addition to giving any other foods 
and fluids such as water or fresh animal milk; and no breast feeding - these infants were given commercial formula feeds or fresh animal milk.

The frequency of nursing during day and night was recorded both for cases and controls, but was difficult to evaluate for the cases because of their severe disease. As a result of this, the amount of breast milk received by the partially breast fed infants is unknown.

\section{STATISTICAL ANALYSIS}

Statistical evaluation was by unmatched analysis for case-control studies, and odds ratios were calculated. Unmatched analysis was used because of the unequal number of controls/case, Mantel and Haenszel's $\chi^{2}$ with one degree of freedom was used for calculation of the significance of differences. Woolfs limits were applied when estimating $95 \%$ confidence intervals (CI). ${ }^{9}$ A test for homogeneity was done after stratifying the various risk factors. ${ }^{10}$

\section{Results}

No significant differences were found between the cases and controls for age, sex, birth order, place of delivery, qualification of birth attendant, interval between rupture of membranes and delivery, sterilisation of instruments used, or handling, cutting, and further care of the cord (table 1). The mode of feeding, however, differed between the cases and controls. The only exclusively breast fed baby, in the control group, was included in the study. In the partially breast fed group there were 19 cases and 253 controls (table 2). In the group that was

Table 1 Comparison of variables in which there was no significant difference between cases of neonatal sepsis and controls. Values are given as number (\%)

\begin{tabular}{|c|c|c|}
\hline & $\begin{array}{l}\text { Cases of } \\
\text { neonatal sepsis } \\
(n=42)\end{array}$ & $\begin{array}{l}\text { Controls } \\
(n=270)\end{array}$ \\
\hline $\begin{array}{l}\text { Age }(0-28 \text { days }): \\
\text { Mean } \\
\text { Median }\end{array}$ & $\begin{array}{l}14 \cdot 8 \\
14\end{array}$ & $\begin{array}{l}15 \cdot 7 \\
16\end{array}$ \\
\hline $\begin{array}{l}\text { Sex: } \\
\text { Male } \\
\text { Female } \\
\text { Median birth order }(1-10)\end{array}$ & $\begin{array}{c}24(57) \\
18(43) \\
3\end{array}$ & $\begin{array}{l}149(55) \\
121(45)\end{array}$ \\
\hline $\begin{array}{l}\text { Place of delivery: } \\
\text { Hospital } \\
\text { Home }\end{array}$ & $\begin{array}{l}14(33) \\
28(67)\end{array}$ & $\begin{array}{r}90(33) \\
180(67)\end{array}$ \\
\hline $\begin{array}{l}\text { Birth attendant: } \\
\text { Doctor } \\
\text { Qualified midwife } \\
\text { Untrained midwife }\end{array}$ & $\begin{array}{r}12(29) \\
22(52) \\
8(19)\end{array}$ & $\begin{array}{r}92(34) \\
154(57) \\
24(9)\end{array}$ \\
\hline $\begin{array}{l}\text { Mode of delivery: } \\
\text { Spontaneous } \\
\text { Forceps } \\
\text { Caesarean }\end{array}$ & $\begin{array}{l}40(95) \\
1 \text { (2) } \\
1 \text { (2) }\end{array}$ & $\begin{array}{r}248(92) \\
14(5) \\
8(3)\end{array}$ \\
\hline $\begin{array}{l}\text { Time between rupture of } \\
\text { membranes and delivery: } \\
0-24 \text { Hours } \\
>24 \text { Hours }\end{array}$ & $\begin{array}{c}41 \text { (98) } \\
1 \text { (2) }\end{array}$ & $\begin{array}{c}260(96) \\
10(4)\end{array}$ \\
\hline $\begin{array}{l}\text { Instruments used for delivery } \\
\text { Sterilised } \\
\text { Unsterilised }\end{array}$ & $\begin{array}{l}24(57) \\
18(43)\end{array}$ & $\begin{array}{l}124(46) \\
146(54)\end{array}$ \\
\hline $\begin{array}{l}\text { Tying of cord: } \\
\text { Clamp } \\
\text { Sterilised thread } \\
\text { Unsterilised thread }\end{array}$ & $\begin{array}{l}10(24) \\
7(17) \\
25(60)\end{array}$ & $\begin{array}{r}65(24) \\
72(27) \\
133(49)\end{array}$ \\
\hline $\begin{array}{l}\text { Care of cord: } \\
\text { Spirit/gentian voilet } \\
\text { Antibiotics } \\
\text { Oil or butter } \\
\text { Ash } \\
\text { Nothing }\end{array}$ & $\begin{array}{r}5(12) \\
14(33) \\
15(36) \\
0 \\
8(19)\end{array}$ & $\begin{array}{r}33(12) \\
96(36) \\
108(40) \\
2(1) \\
31(12)\end{array}$ \\
\hline
\end{tabular}

Table 2 Occurrence of sepsis and mode of feeding

\begin{tabular}{|c|c|c|c|c|}
\hline & $\begin{array}{l}\text { No (\%) of } \\
\text { cases of } \\
\text { neonatal } \\
\text { sepsis }\end{array}$ & $\begin{array}{l}\text { No (\%) of } \\
\text { controls }\end{array}$ & $x^{2}$ & $\stackrel{p}{\text { Value }}$ \\
\hline $\begin{array}{l}\text { Animal milk } \\
\text { or formula }\end{array}$ & $23(55)$ & $17(6)$ & $71 \cdot 8$ & $<0.001^{* *}$ \\
\hline $\begin{array}{l}\text { Partial breast } \\
\text { feeding }\end{array}$ & $19(45)$ & $253(94)^{*}$ & & \\
\hline Total & 42 & 270 & & \\
\hline
\end{tabular}

given no breast milk there were 23 cases and 17 controls. The incidence of breast feeding was less among the cases than the controls, with an odds ratio of 18 . The odds ratio did not vary significantly when the data were stratified for sex, birth order, place of delivery, and qualification of the birth attendant, or instruments used (data not shown).

\section{Discussion}

This study indicates that protection against neonatal sepsis is given even with partial breast feeding among neonates in a poor community with a high mortality from neonatal sepsis.

In these severely ill infants the diagnosis was usually obvious and there were few differential diagnoses. This was especially true because no case of early neonatal sepsis, which can be difficult to diagnose, was seen in this study. It is possible that early cases of neonatal sepsis died at home before they had time to reach hospital.

The septicaemic infants were not less likely to be breast fed than the controls. This is based on our findings that in the study area $98 \%$ of those that are going to be breast fed have started breast feeding on or before day 3 and all are being breast fed by day $5 .^{6}$ In 39 of the 42 cases, the onset of septicaemia was after day 4 , and only three presented on day 3 .

Not only was exclusive breast feeding uncommon in the community that we studied but colostrum was rarely fed. Instead, various otheroften infected-foods and fluids were given. This may explain why the intestinal tracts of neonates in the study area were colonised with aerobic Gram negative bacteria significantly earlier than those of Swedish infants. ${ }^{11}$ In addition, the early aerobic gut flora of Pakistani infants contained bacteria of more genera compared with those of Swedish infants. Klebsiella, enterobacter and citrobacter were also significantly more common among the nonbreast fed Pakistani infants than among those that had early breast feeding. This early exposure to various bacterial strains might result in an unstable and potentially pathogenic gut flora that causes early infections such as neonatal sepsis and diarrhoea, which are common in this community. It is possible that the early microbial exposure and lack of feeding with colostrum could cause the severe cases.

Although the events at the time of delivery like mode of delivery, and risk factors such as sex, birth order, place of delivery, qualification of birth attendant, interval between rupture of membranes and delivery, and techniques of 
cord care were evenly distributed among both cases and controls, there was a significant difference between the groups in the mode of feeding. The study includes unequal numbers of controls for each case because of the preset matching criteria that were used. There is no reason to believe that cases with more controls are different from those with fewer controls with regard to background measures of importance. We have not tested this statistically because the lowest number of controls selected for any one case was four. If exactly four of the controls were selected for each case, the total number of controls would be 168 . Theoretically, all the deleted controls $(n=102)$ could belong to the partial breast fed group (table 2). Seventeen of the controls would then still not be breast fed, but 'only' 151 , or $89 \%$, would be partially breast fed. In this extreme situation the odds ratio is $10.8(\mathrm{p}<0.001)$ and the conclusion of the study would thus not be influenced.

Of the total cases, $45 \%$ were partially breast fed compared with $94 \%$ of the controls, so this study shows that even partial breast feeding can protect infants from neonatal sepsis. Possibly exclusive breast feeding would provide even better protection. In developing countries, therefore, exclusive breast feeding (including early colostrum feeding) should be promoted by teaching birth attendants and giving information to the family.

We thank Ms Fatima Aziz and Azra Perveen for valuable help in the field work. The study was supported by grants from the Swedish Agency for Research Cooperation with Developing Countries and the Swedish Medical Research Council.

1 Bennet R, Eriksson M, Melen B, Zetterström R. Changes in the incidence and spectrum of neonatal septicemia during a

2 Vesikari T, Janas M. Grönroos P, et al. Neonatal septicaemia. Arch Dis Child 1985;60:542-6.
A

3 Mir F, Aman S, Khan SR. Neonatal sepsis: a review with a Mir F, Aman S, Khan SR. Neonatal sepsis: a review
study of 50 cases. I Trop Pediatr 1987;33:131-4.

4 Ohlsson A, Serenius F. Neonatal septicemia in Riyadh, Saudi Arabia. Acta Paediatr Scand 1981;70:825-9.

5 Bennet R, Bergdahl S, Eriksson M, Zetterström F. The outcome of neonatal septicemia during fifteen years. Acto Paediatr Scand 1989:78:40-3.

6 Hanson LA, Adlerberth I, Carlsson B, et al. Breastfeeding in reality. In: Hamosh M, Goldman A, eds. Human lactation 2. Matemal and environmental factors. New York: Plenum Publishing Corporation, 1986:1-12.

7 Winberg J, Wessner G. Does breast milk protect against septicaemia in the newborn? Lancet 1971; $1091-4$.

8 Jalil F, Adlerberth I, Ashraf R, et al. Methodological problems in assessment of long term health outcomes in breast-fed versus bottle-fed infants. In: Atkinson S, Hanson LA, Chandra RK, eds. Human lactation 4. BreastHanson LA, Chandra RK, eds. Human lactation 4. Breastfeeding, nutrition, infection and infant growth in developed and 1990:381-94.

9 Schlesselman JJ. Case-control studies. Design, conduct, analysis. Oxford: Oxford University Press, 1982.

10 Breslow NE, Day NE. The analysis of case control studies. Statistical methods in cancer research. Vol 1. IARC Scientific Publication No. 32. Lyon: International Agency for Research in Cancer, 1980

11 Adlerberth I, Carlsson B, de Man P, et al. Intestinal colonisation with enterobacteriaceae in Pakistani and Swedish hospital-delivered infants. Acta Paediatr Scand (in press). 